\title{
Association between single nucleotide polymorphism of immunoregulatory genes and preterm premature rupture of membranes in preterm labour
}

\author{
K. S. Liubomyrska, O. M. Kamyshnyi, Yu. Ya. Krut
}

Zaporizhzhia State Medical University, Ukraine

Aim. Investigation of the association between SNP genes of IL4 (rs2243250), IL10 (rs1800896 and rs1800872) and RLN2 (rs4742076 and rs3758239) and preterm premature rupture of membranes in 26-34 weeks of gestation in Zaporizhzhia population.

Materials and methods. We have investigated markers of cytokines genes in 50 women with PPROM in 26-34 weeks of gestation period and 50 pregnant women with physiological pregnancy and term labour without complications. The genotyping using TaqMan tests was done on amplifier CFX96 ${ }^{\mathrm{TM}}$ Real-Time PCR Detection Systems (Bio-Rad Laboratories, Inc., USA. The combined effect of the studied locus of the analyzed genes on the appearance of PPROM, PTL in the population was initiated using the Multifactory Dimensionality Reduction (MDR) method (software MDR ver. 3.0.2).

Results. The distribution of the rs2243250 gene polymorphism alleles of the IL4 gene of the main study group - TT homozygotes were determined in $4 \%$ cases, CT heterozygotes were found in $22 \%$, CC homozygotes - in $74 \%$ cases. We have got statistically significant differences of rs4742076 polymorphisms (TT, CT, and CC) of the RLN2 gene in the study groups. We also detected statistically significant differences in all the alleles of rs3758239 polymorphism (AA, GG and AG) of the gene RLN2 $-X^{2}=23.86, \mathrm{OR}(A A)=12.57 ; 95 \% \mathrm{Cl}: 3.68-42.98 ; \mathrm{OR}(G G)=0.08 ; 95 \% \mathrm{Cl}: 0.02-0.27$; and $\mathrm{OR}(A G)=$ $0.11 ; 95 \% \mathrm{Cl}: 0.03-0.42$, respectively, $\mathrm{P}<0.05$, indicating the reliability of the received prognostic markers. The nature of interlocal interaction between the genes is at the level of "independent effects" of influence (IL4-IL10 rs1800896 $=-23.08 \%$, IL10 rs1800896 - IL10 rs1800872 = -19.94 \%, IL10 rs1800872-IL-4 = -19.34 \%). The percentage of entropy of the investigated polymorphism of each gene for the case-control status was $14.15 \%$ for the IL 4 gene, $23.08 \%$ for the IL10 rs1800896 gene and $9.34 \%$ for the IL10 rs1800872 gene.

Conclusions. Combination of IL4 rs2243250, IL10 rs1800896 and rs1800872 supports the role for functional polymorphisms in immunoregulatory genes in the development of PPROM and PTL. Reliable clinical association of rs 4742076 and rs 3758239 gene RLN2 was established with the PPROM in 26-34 weeks' gestation in Zaporizhzhia population.

\section{Асоціація однонукиеотидного поліморфізму імунорегуляторних генів із передчасним розривом плодових оболонок при недоношеній вагітності}

\section{К. С. Любомирська, О. М. Камишний, Ю. Я. Круть}

Мета роботи - дослідити асоціацію однонуклеотидного поліморфізму генів IL4(rs2243250), IL10 (rs1800896 та rs1800872), RLN2 (rs4742076 та rs3758239) із передчасним розривом плодових оболонок (ПРПО) у 26-34 тижні гестації в популяції Запорізького регіону.

Матеріали та методи. Здійснили дослідження маркерів генів цитокінів у 50 жінок з ПРПО в терміні гестації 26-34 тижні та 50 вагітних із фізіологічним перебігом вагітності та терміновими пологами без ускладнень. Генотипування за допомогою TaqMan проб виконали на ампліфікаторі CFX96 ${ }^{\mathrm{TM}}$ Real-Time PCR Detection Systems («Bio-Rad Laboratories, Inc.», США). Для моделювання та аналізу міжгенних взаємодій використали метод багатофакторного зменшення розмірності (MDR - Multifactory Dimensionality Reduction - program version 3.0.2).

Результати. За результатами генотипування поліморфізму rs1800896 гена IL 10 гомозиготи TT виявлені у 74 \% випадків основної групи дослідження, гетерозиготи TC-у 4 \%, гомозиготи CC-у 22 \% випадків. Розподіл алелей поліморфізму rs2243250 гена IL4 основної групи дослідження: гомозиготи TT визначені у 4 \% випадків, гетерозиготи CT - у $22 \%$, гомозиготи CC - у 74 \%. Виявили статистично значущі відмінності за кожною з алелей поліморфізму rs4742076 (TT, CT та CC) гена RLN2 між основною групою дослідження та групою контролю. Отримали статистично вірогідні дані, порівнюючи основну та групу контролю, зокрема за всіма алелями поліморфізму rs3758239 (AA, GG та $A G)$ гена RLN2 $-X^{2}=23,86, \mathrm{OR}(A A)=12,57 ; 95 \% \mathrm{Cl}: 3,68-42,98 ; \mathrm{OR}(G G)=0,08 ; 95 \% \mathrm{Cl}: 0,02-0,27 ; \mathrm{OR}(A G)=0,11 ; 95 \% \mathrm{Cl}$ : $0,03-0,42$ відповідно, $p<0,05$.

Характер міжлокусної взаємодії між генами - на рівні «незалежні ефекти» впливу (IL4-IL10 rs1800896 = -23,08 \%, IL10 rs1800896 - IL10 rs1800872 = -19,94 \%, IL10 rs1800872-IL-4 = -19,34 \%). Частка ентропії досліджуваного поліморфрізму кожного гена щодо статусу «випадок - контроль» становила 14,15 \% для IL4, 23,08 \% - для IL10 rs1800896 гена, 9,34 \% - для IL10 rs1800872 гена.

Висновки. Комбінація IL4 rs2243250, IL10 rs1800896 та rs1800872 підтверджує роль поліморфізму імунорегуляторних генів у розвитку ПРПО та передчасних пологів. У популяції Запорізького регіону наявна вірогідна клінічна асоціація rs4742076 та rs3758239 гена RLN2 та ПРПО в терміні гестації 26-34 тижні.
Key words: preterm labour, preterm premature rupture of membranes, single nucleotide polymorphism.

Pathologia 2018; 15 (2), 187-193 DOl: 10.14739/2310-1237 2018.2.141400

E-mail: lubomirskaae@ gmail.com

Ключові слова: передчасні пологи, передчасний розрив плоАОВих ОболОНОК, ОАНОНуклеОтиАниЙ поліморфізм генів.

Патологія. - 2018. -

T. 15, № 2(43). C. $187-193$ 
Ключевые слова: преждевременные роды, преждевременный разрыв плодных оболочек, оАнонуклеотиАНЫЙ полиморфизм генов.

Патология. - 2018. T. 15, № 2(43). C. 187-193

\section{Ассоциация однонуклеотидного полиморфизма иммунорегуяяторных генов с преждевременным разрывом плодных оболочек при недоношенной беременности}

\section{Е. С. Аюбомирская, А. М. Камышный, Ю. Я. Круть}

Цель работы - определить ассоциацию однонуклеотидного полиморфизма генов IL4(rs2243250), IL10 (rs1800896 и rs1800872), RLN2 (rs4742076 и rs3758239) с преждевременным разрывом плодных оболочек (ПРПО) в $26-34$ недели гестации в популяции Запорожского региона.

Материалы и методы. Исследовали маркеры генов цитокинов у 50 женщин с ПРПО в сроке гестации 26-34 недели и 50 беременных с физиологическим течением беременности и срочными родами без осложнений. Генотипирование с помощью TaqMan проб проведено на амплификаторе CFX96 ${ }^{\text {TM }}$ Real-Time PCR Detection Systems («Bio-Rad Laboratories, Inc.», США). Для моделирования и анализа межгенного взаимодействия использовали метод многофакторного уменьшения размеренности (MDR - Multifactory Dimensionality Reduction - program version 3.0.2).

Результаты. По результатам генотипирования полиморфизма rs 1800896 гена IL 10 гомозиготы TT установлены в 74 \% случаев основной группы исследования, гетерозиготы ТС - у 4 \%, гомозиготы СС - в 22 \% случаев. Распределение аллелей полиморфизма rs 2243250 гена IL4 основной группы исследования: гомозиготы TT определены в 4 \% случаев, гетерозиготы CT - в $22 \%$, гомозиготы CC - в 74 \%. Установлены статистически значимые различия по каждой аллели полиморфизма rs4742076 (ТT, СТ и CC) гена RLN2 между группами исследования. Получены статистически достоверные данные в сравнении основной и группы контроля, в том числе по всем аллелям полиморфизма rs3758239 (AA, GG и AG) гена RLN2 $-X^{2}=23,86, \mathrm{OR}(\mathrm{AA})=12,57 ; 95 \% \mathrm{Cl}: 3,68-42,98 ; \mathrm{OR}(\mathrm{GG})=0,08 ; 95 \% \mathrm{Cl}: 0,02-0,27 ; \mathrm{OR}(\mathrm{AG})=0,11$; $95 \% \mathrm{Cl}: 0,03-0,42$ соответственно $\mathrm{p}<0,05$. Характер межлокусного взаимодействия между генами на уровне «независимые эффекты» влияния - IL4-IL10 rs1800896 = -23,08 \%, IL10 rs1800896 - IL10 rs1800872 = -19,94 \%, IL10 rs1800872-IL-4 = -19,34\%. Доля энтропии исследуемого полиморфизма каждого гена статуса «случай - контроль» составила 14,15 \% для IL4, 23,08 \% - для IL10 rs1800896 гена, 9,34 \% - для IL10 rs1800872 гена.

Выводы. Комбинация IL 4 rs2243250, IL10 rs1800896 и rs1800872 подтверждает роль полиморфизма иммунорегуляторных генов в развитии ПРПО и преждевременных родов. Установлена достоверная клиническая ассоциация rs 4742076 и rs3758239 гена RLN2 с возникновением ПРПО в сроке гестации 26-34 недели в популяции Запорожской области.

\section{Background}

Today in Ukraine the number of normal births is an average of $32.6 \%$ of their total. The frequency of registration of the prematurity in different regions of the country ranges from $3 \%$ to $12 \%$. Spontaneous preterm labor (PTL) and preterm premature rupture of membranes (PPROM) are major contributors to neonatal mortality and serious neonatal morbidity worldwide [3]. Despite all efforts to identify preventive measures and causative mechanisms, prematurity remains an unresolved issue worldwide [5].

In recent years a great attention has been paid to associative search of polymorphic markers with different diseases and as a result creation the genetic platform for personalized medicine. However, the genetic predisposition can contribute to PTL and PPROM [11]. The sequencing of the human genome and the discovery of the phenomenon of single nucleotide polymorphism (SNP) genes became a dawn of studying the effect of the genetic code on quantitative expression changes and further biological function of proteins [8,9]. Most of the SNP genes of the cytokines are found in the regulatory regions of the gene and directly affect their transcriptional activity and the concentration of the cytokine in the blood [4]. These genetic variations have an effect on the individual characteristics involved the immune response to infection and triggering PTL and PPROM [6,7]. Most of findings, however, are controversial, which demonstrates the importance of standardized methods and reproductive techniques as well as strictly performed evaluation adjusted for potential confounding factors [3]. Additionally, great part of inconsistencies found in the literature can be due to differences in genetic background and environmental exposures, parameters that vary greatly among distinct populations [3].
But information about the polymorphism of signaling molecules during PPROM in preterm pregnancy is small, scientific work in this direction can provide resources for analysis of polymorphic markers in associative studies, deepen the concept of the immune link of PPROM and PTL pathways, develop new effective methods of prediction these complications of pregnancy $[10,12]$.

\section{Aim}

To investigate the association between SNP genes of IL4 (rs2243250), IL10 (rs1800896 and rs1800872) and RLN2 (rs4742076 and rs3758239) and preterm premature rupture of membranes in 26-34 weeks of gestation in Zaporizhzhia population.

These SNPs genes were selected based on existing evidence in the literature for a role in the pathogenesis of the studied conditions.

\section{Materials and methods}

We had done open cohort randomized research based on Regional Perinatal Center Zaporizhzhia city during period of 2015-2017 years. The case group consisted of 50 women with PPROM in preterm pregnancy, 26-34 weeks of gestation. For the control group we collected samples from 50 women with healthy term deliveries without previous history of PTL.

The genotyping using TaqMan tests was done on amplifier CFX96 ${ }^{\text {TM }}$ Real-Time PCR Detection Systems (Bio-Rad Laboratories, Inc., USA). Polymerase chain reaction (PCR) for TaqMan genotyping was performed according to the instructions of Applied Biosystems, USA. 


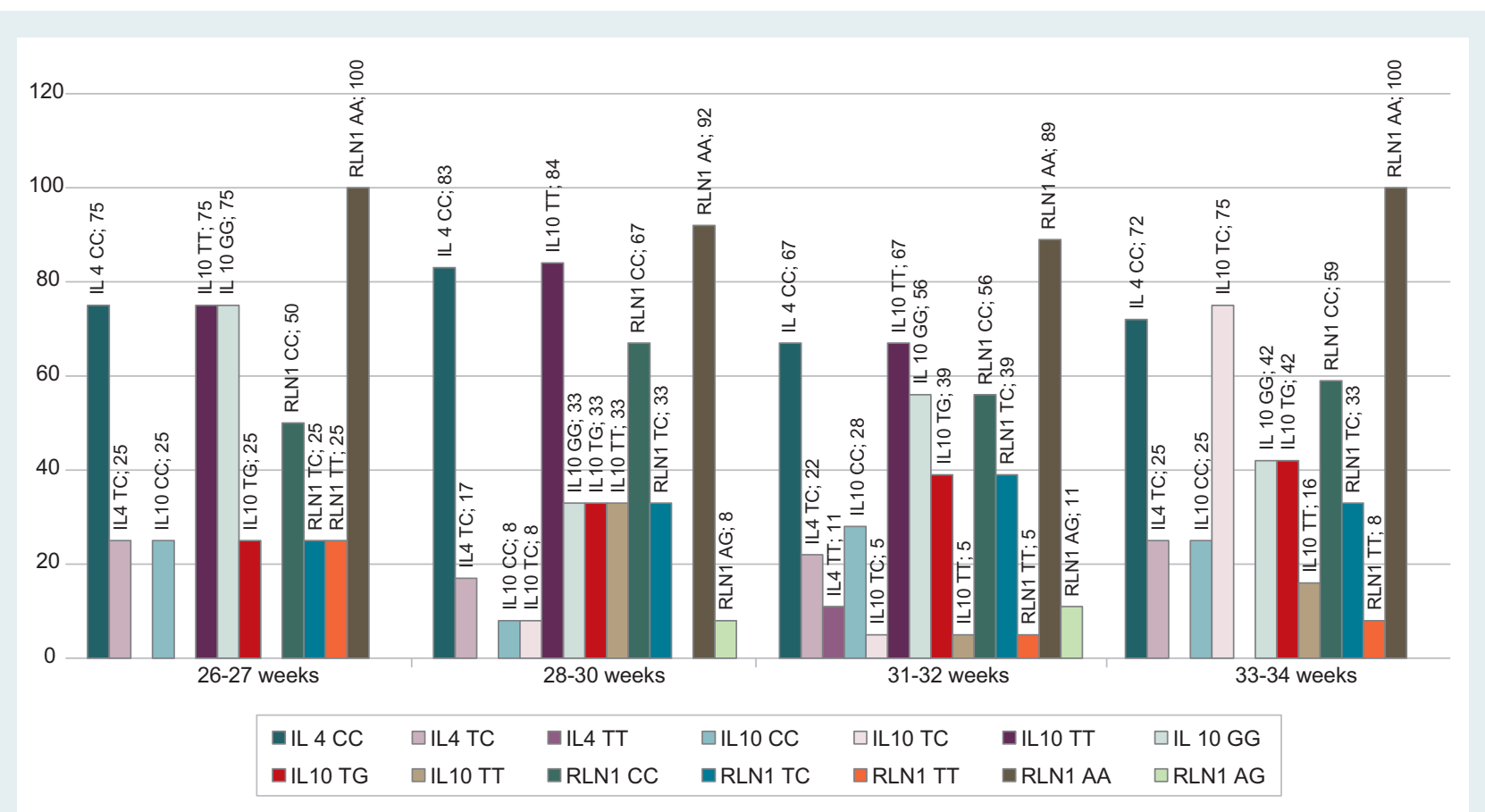

Fig. 1. Distribution of alleles/genotypes of genes IL4 rs2243250, IL10 rs1800896, IL10 rs1800872, RLN2 rs4742076, RLN2 rs3758239 depending on manifestation term of the PPROM (\%).

Statistical data processing was carried out using the software package Statistica 6.0 (StatSoft Inc, No. AXXR712D833214FAN5). The comparison of qualitative indices was carried out using the $X^{2}$ criterion with Yates's correction and Fischer's exact test $(F)$. In order to evaluate the contribution of gene polymorphism to the probability of development of PPROM in preterm pregnancy, odds ratios (OR) were calculated with $95 \%$ confidence interval $(\mathrm{Cl})$. The differences were considered to be significant at $\mathrm{P}<0.05$.

The combined effect of the studied locus of the analyzed genes on the appearance of PPROM, PTL in the population was initiated using the Multifactory Dimensionality Reduction (MDR) method, a nonparametric statistical method that evaluates the main, independent and common effects of gene polymorphism, from deducting potential of the predicate (software MDR ver. 3.0.2). Also using the MDR method predicted the risks of PPROM, PTL with a graphic model of gene-gene interaction. The best gene-gene interaction patterns were characterized by the highest cross-validation consistency.

\section{Results}

Based on the genotyping results of rs1800896 gene polymorphism IL-10 gene TT homozygotes were detected in $37(74 \%)$ cases of the main study group, CT heterozygotes - in $2(4 \%)$ and CC homozygotes - in 11 ( $22 \%$ ) cases, consequently. In the study of polymorphism rs1800872 of the IL10 gene, in the main group of study homozygous TT were identified in $7(14 \%)$ cases, TG heterozygotes were found in 18 (36\%), GG homozygotes - in $25(50 \%)$ cases.
The distribution of the rs2243250 gene polymorphism alleles of the IL4 gene of the main study group - TT homozygotes were determined in $2(4 \%)$ cases, CT heterozygotes were found in $11(22 \%)$, CC homozygotes in $37(74 \%)$ cases. The prevalence of genotypes depending on term of PPROM is demonstrated in Fig. 1.

We have got statistically significant differences of rs4742076 polymorphisms (TT, CT, and CC) of the RLN2 gene in the study groups $\left(X^{2}=25.46, \mathrm{OR}(T T)=33.0\right.$; $95 \%$ Cl: 4.37-249.1; OR $(C T)=25.24 ; 95 \% \mathrm{Cl}$ : 3.20-198.96; and $\mathrm{OR}(C C)=0.03 ; 95 \% \mathrm{Cl}: 0.00-0.23$, respectively $P<0.05)$. We also detected statistically significant differences in all the alleles of rs3758239 polymorphism (AA, GG and AG) of the gene RLN2 $X^{2}=23.86, O R(A A)=12.57 ; 95 \% \mathrm{Cl}: 3.68-42.98$; $\mathrm{OR}(\mathrm{GG})=0.08 ; 95 \% \mathrm{Cl}: 0.02-0.27 ; \mathrm{OR}(\mathrm{AG})=0.11$; $95 \% \mathrm{Cl}: 0.03-0.42$, respectively $\mathrm{P}<0.05$, indicating the reliability of the received prognostic markers. The received data of frequency of alleles/genotypes distribution is set in Figure 2 and 3.

The analysis of the multiplicative model of inheritance has shown that the relative frequency of the investigated polymorphic variants of genes IL4 (rs2243250), IL10 (rs1800896 and rs1800872) and RLN2 (rs4742076 and rs3758239) was significantly different between the study groups (Table 1). In general, the favorable CC polymorphic variant of the IL4 (rs2243250) gene over TT was dominant in the surveyed population (18.5 times more among patients $(P<0.05), 9.33$ times - among healthy term deliveries $(P<0.05)$, T-alleles of the IL10 (rs2243250) gene over TC polymorphic variant (18.5 times among patients $(P<0.05), 5.5$ times among healthy $(P<0.05)$, GG genotype of IL10 (rs1800872) gene over TT polymorphism (3.57 times among patients $(P<0.05), 18.5$ times among 


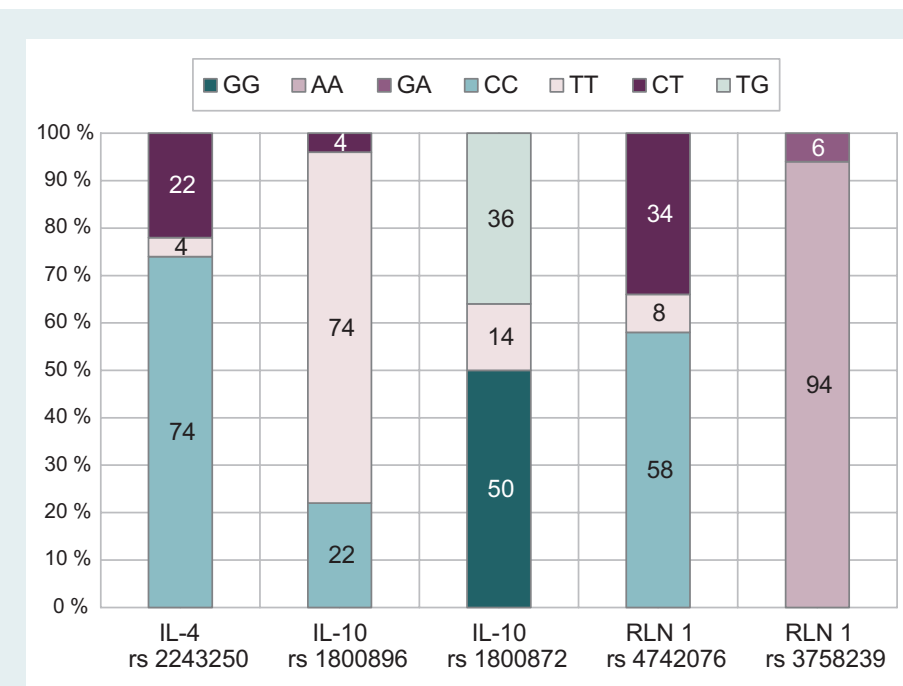

Fig. 2. Frequency of genotypes distribution in women with PPROM and PTL (\%).

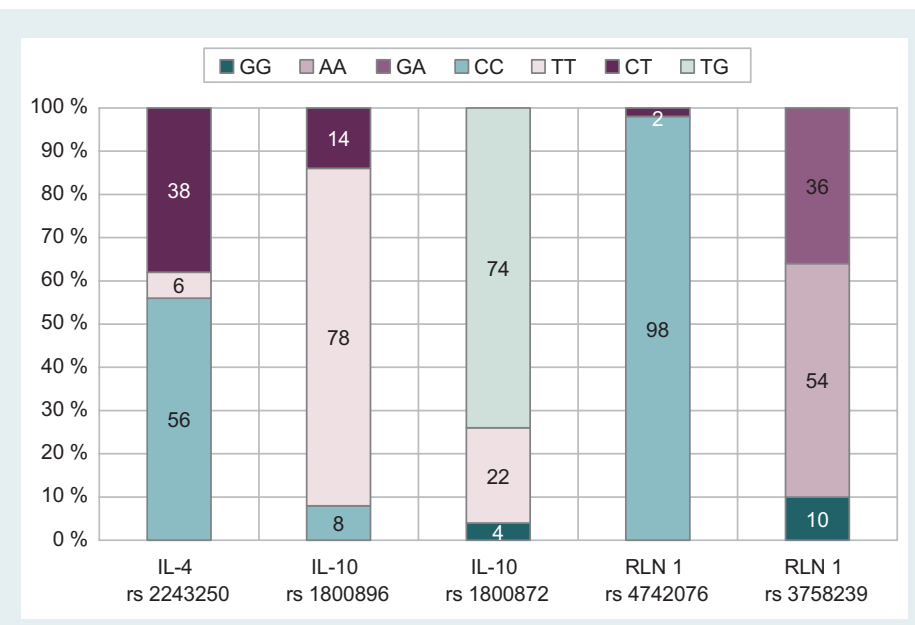

Fig. 3. Frequency of genotypes distribution in women with physiological pregnancy and labour (\%). healthy $(P<0,05)$. Regarding of the RLN2 (rs4742076) gene the favorable CC variant over polymorphic CT was dominant in the surveyed population (1.71 times among patients $(P<0.05), 49$ times among control group $(\mathrm{P}<0.05)$, C-alleles over T-alleles -7.25 times among women with PPROM. It should be noted that TT genotype was absent in control group. Concerning the frequency of polymorphic variants in RLN2 (rs3758239) the favorable AA variant over AG (15.7 times more in patients $(P<0.05)$, 1.5 times among healthy term labour $(P<0.05), A$-alleles prevails over $\mathrm{G}$-alleles (47 times in patients $(\mathrm{P}<0.05), 5.4$ times among control $(P<0.05)$.

The best gene-gene interaction models including taking into account the balanced testing and training accuracy, the highest cross-validation consistency, high sensitivity and specifity are given in Table 2. Combinations of best MDR models associated with high and low risk of PPROM are graphically presented in Fig. 4 and in Fig. 6 - polymorphic variants of best MDR models in term deliveries.

The circular graph of the cluster analysis of the results of gene-gene interaction simulation using the MDR-method is shown in Figure 5. The nature of interlocal interaction between the genes is at the level of «independent effects» of influence (IL4-IL10 rs1800896 $=-23.08 \%$, IL10 rs1800896 - IL10 rs1800872 = -19.94 \%, IL10 rs1800872$\mathrm{IL}-4=-19.34 \%$ ). The percentage of entropy of the investigated polymorphism of each gene for the case-control status was $14.15 \%$ for the IL4 gene, $23.08 \%$ for the IL 10 rs 1800896 gene and $9.34 \%$ for the IL 10 rs 1800872 gene, indicating the high significance of the all present genes and their significant effect on the appearance of PPROM in preterm pregnancies.

In control group with term healthy pregnancy and labour the percentage of entropy of the investigated polymorphism of each gene, based on the results of the cluster analysis, simulates gene-gene interaction, is high and makes for the gene IL4 - $29.55 \%$, for IL10 rs1800896 - $14.74 \%$, for IL10 rs1800872 - $7.89 \%$ (Figure 7), in the presence of an independent but sta-

Table 1. Association between polymorphic locks of cytokine genes and high risk of PPROM and PTL in Zaporizhzhia region

\begin{tabular}{|c|c|c|c|c|c|c|}
\hline SNPs & Allel / Genotype & Public location & OR & $95 \% \mathrm{Cl}$ & $x^{2}$ & P-value \\
\hline IL4 rs2243250 & $\begin{array}{l}\text { Allel C } \\
\text { Genotype CT } \\
\text { Allel T }\end{array}$ & 132673462 & $\begin{array}{l}3.94 \\
4.42 \\
0.25\end{array}$ & $\begin{array}{l}2.0-7.76 \\
1.15-16.97 \\
0.13-0.50\end{array}$ & 16.77 & $4 \times 10^{-5 *}$ \\
\hline IL10 rs1800896 & $\begin{array}{l}\text { Genotype CC } \\
\text { Genotype CT } \\
\text { Genotype TT }\end{array}$ & 206773552 & $\begin{array}{l}3.24 \\
0.26 \\
0.8\end{array}$ & $\begin{array}{l}1.07-11.00 \\
0.05-0.93 \\
0.32-0.84\end{array}$ & 6.1 & 0.05 * \\
\hline IL10 rs1800872 & $\begin{array}{l}\text { Allel T } \\
\text { Genotype TG } \\
\text { Allel G }\end{array}$ & 206773062 & $\begin{array}{l}0.33 \\
0.2 \\
24.0\end{array}$ & $\begin{array}{l}0.18-0.58 \\
0.08-0.47 \\
5.25-109.65\end{array}$ & 14.7 & 0.0001 * \\
\hline RLN2 rs 4742076 & $\begin{array}{l}\text { Allel C } \\
\text { Allel T }\end{array}$ & 5309831 & $\begin{array}{l}0.03 \\
33.0\end{array}$ & $\begin{array}{l}0.00-0.23 \\
4.37-249.1\end{array}$ & 25.46 & $5 \times 10^{-7}$ * \\
\hline RLN2 rs3758239 & $\begin{array}{l}\text { Allel A } \\
\text { Allel G }\end{array}$ & 5306824 & $\begin{array}{l}12.57 \\
0.08\end{array}$ & $\begin{array}{l}3.68-42.98 \\
0.02-0.27\end{array}$ & 23.86 & $1 \times 10^{-6}$ * \\
\hline
\end{tabular}

*: reliability of the difference, $P<0.05$.

Table 2. Best MDR models SNPs associated with high risk of PPROM and PTL in Zaporizhzhia region

\begin{tabular}{|c|c|c|c|c|c|c|}
\hline Model SNPs & Balanced accuracy & $\begin{array}{l}\text { Cross-validation } \\
\text { consistency }\end{array}$ & Sensitivity & Specifity & $x^{2}$ & P-value \\
\hline IL4 rs2243250 & 0,7589 & $9 / 10$ & 1.0 & 0.8298 & 11.3153 & 0.0008 \\
\hline IL4 rs2243250 + IL10 rs1800896 & 0,9232 & $10 / 10$ & 1.0 & 0.8468 & 11.1172 & 0.0008 \\
\hline IL4 rs2243250 + IL10 rs1800896 + IL10 rs1800872 & 0,9149 & $10 / 10$ & 1.0 & 0.8298 & 11.3153 & 0.0008 \\
\hline
\end{tabular}




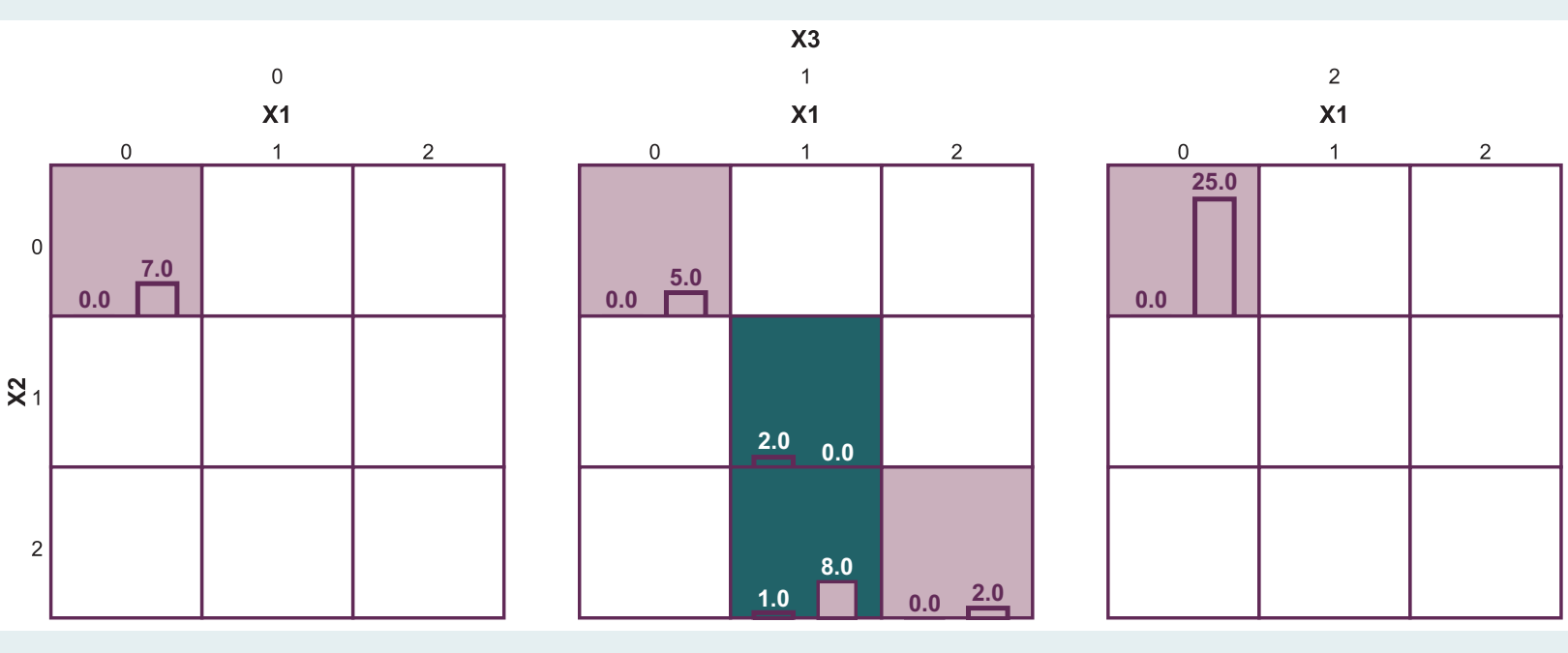

Fig. 4. Combination of polymorphic variants of genes X1 (IL4 rs 2243250), X2 (IL10 rs1800896), X3 (IL10 rs1800872) associated with high (dark gray cell) and low risk (light gray cell) of PPROM and PTL in Zaporizhzhia population.

IL4 (rs 2243250) 0, 1, 2: polymorphic variants of IL4 gene CC (0), TC (1), TT (2); IL10 (rs1800896) 0, 1, 2: polymorphic variants of IL10 gene TT (0), TC (1), CC (2); IL10 (rs1800872) 0, 1, 2: polymorphic variants of IL10 gene TT (0), TG (1), GG (2).

tistically significant effect on the occurrence of PPROM in PTL in the Zaporizhzhia surveyed population. The nature of interlocal interaction between the genes is at the level of «antagonistic effects» of influence (IL4IL10 rs1800896 = -14.74\%, IL10 rs1800896 - IL10 rs1800872 = -14.76\%, IL10 rs1800872-IL-4 = -7.89\%).

\section{Discussion}

The data that we received in our work were compared with the results of other scientists. It should be note at once that the number of studies on genetic polymorphism in relation to PPROM and PTL has dramatically multiplied. In addition, the results of studies of the same gene polymorphisms are determined by the design of the study, the choice of patient groups, are significantly differentiated in different populations and ethnic groups, and the expression of these mutations depends on a combination of culturological, socioeconomic and semantic factors, which are determined by the style of life in general and the style of habitation, in particular. However, many of polymorphisms exhibit inconsistency and remain inconclusive.

Being a global problem preterm birth warrants global solutions. Recent genomic approaches are beginning to reveal the information for understanding the causes of PTL. To fully appreciate and understand the complexity of PPROM and PTL, further approaches using high-throughput genome sequencing methods such as whole-genome sequencing studies are essential. Therefore, the challenge is to identify high risk women and provide them a personalized medical care for reducing the burden of PTL.

Common biological pathways that play important role in the pathogenesis of PTL are infections and inflammation, maternal-fetal hypothalamopituitary adrenal activation, decidual defects and pathological uterine overdistension. PTL has multifactorial origins and often several systems in the body and many different factor classifications interact in increasing the risk of PTL. In

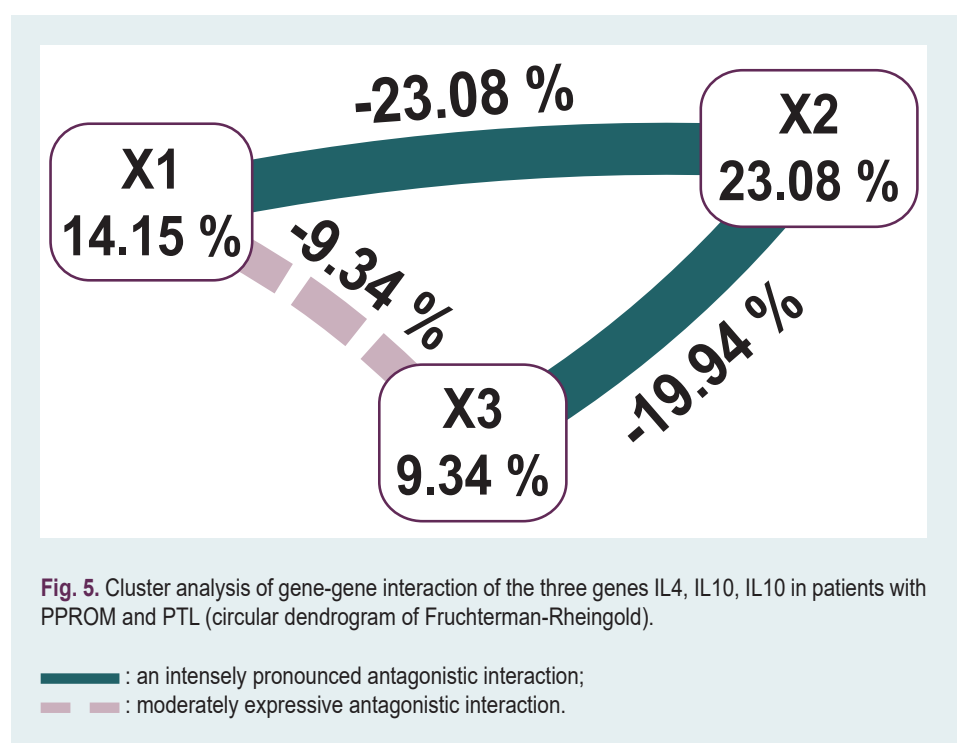

the contrast, it is estimated that only $50 \%$ of PTLs can be assigned to a known risk or causative factor, while the rest remain idiopathic.

In connection with the above, there was a need for the study of frequent mutations of genes IL4 (rs2243250), IL10 (rs1800896 and rs1800872) and RLN2 (rs4742076 and rs3758239) in Zaporizhzhia population to determine their role in the pathogenesis of PPROM and PTL in order to identify patterns and mechanisms for the formation of PPROM, the division of high-risk groups, early diagnosis, prediction and prophylactics. In Ukraine, the study of such a combination of genes in the pathology of software at the start of this study was not conducted.

In the study performed by A. Heinzmann haplotypes IL13/IL4 in a German population were presented as associated with PTL [2]. We proved association of IL4 rs2243250 with high risk or PPROM in Zaporizhzhia region. IL10 is an anti-inflammatory cytokine and at- 


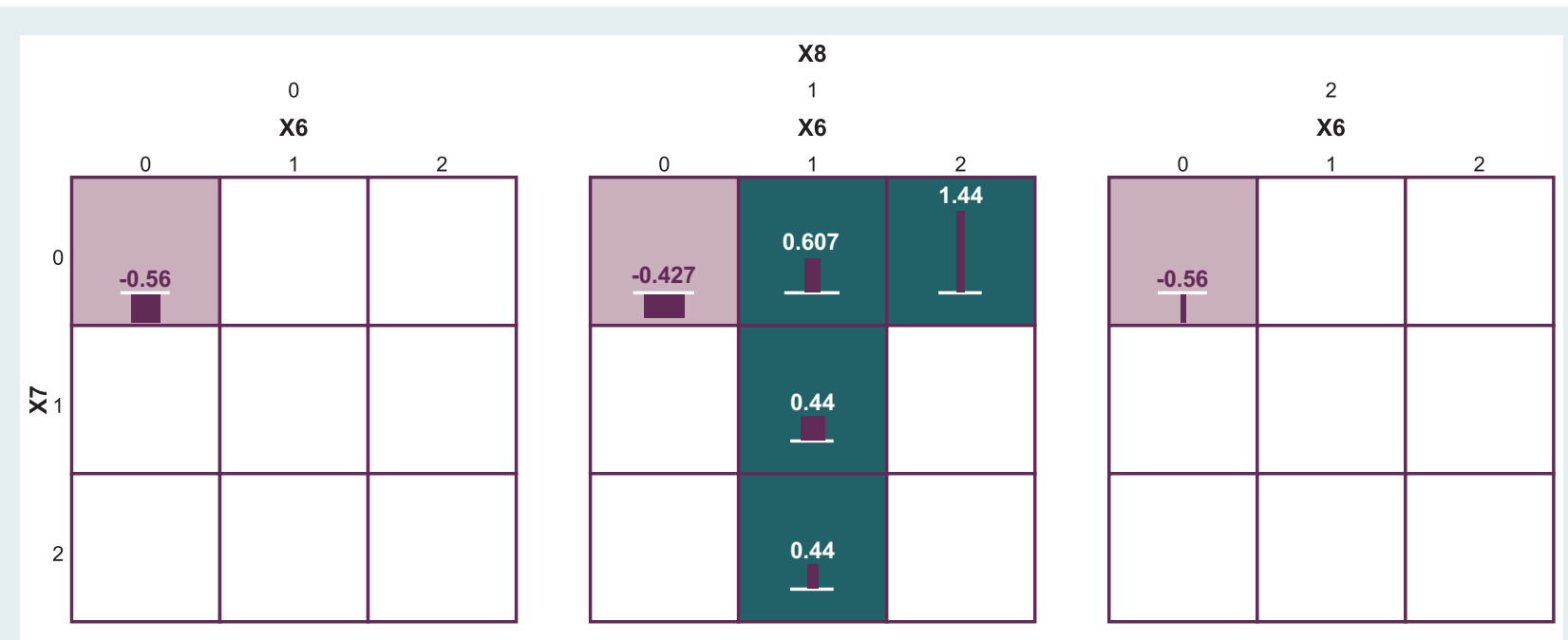

Fig. 6. Combination of polymorphic variants of genes X6 (IL4 rs 2243250), X7 (IL10 rs1800896), X8 (IL10 rs1800872) associated with healthy term deliveries in Zaporizhzhia population.

IL4 (rs 2243250) 0, 1, 2: polymorphic variants of IL4 gene CC (0), TC (1), TT (2); IL10 (rs1800896) 0, 1, 2: polymorphic variants of IL10 gene TT (0), TC (1), CC (2); IL10 (rs1800872) 0, 1, 2: polymorphic variants of IL10 gene TT (0), TG (1), GG (2).

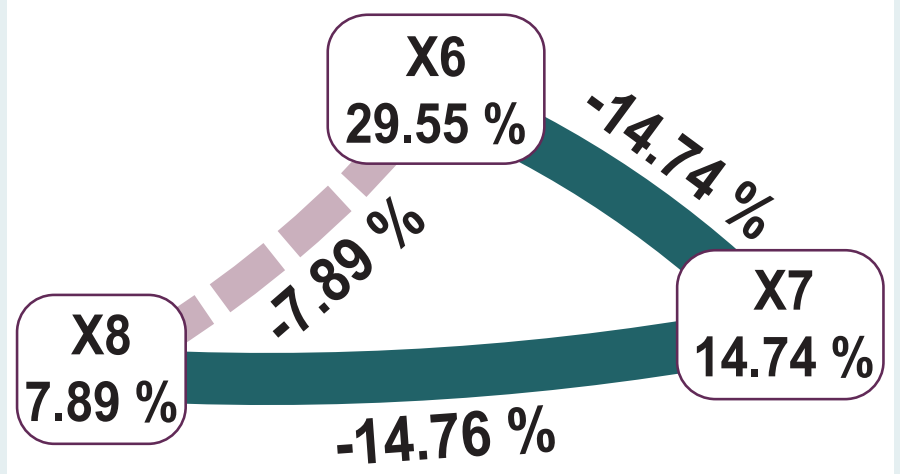

Fig. 7. Cluster analysis of gene-gene interaction of three genes IL4, IL10, IL10 in women with healthy term deliveries (circular dendrogram of Fruchterman-Rheingold).

: an intensely pronounced antagonistic interaction

- moderately expressive antagonistic interaction.

tenuates the inflammatory response through effects on pro-inflammatory cytokines and reduces the function of host immune cells, such as neutrophils and macrophages. Stonek F., Metzenbauer M. in their studies have found no association of IL10 with PTL [1]. Results of our study are controversial to researches of $\mathrm{F}$. Stonek. We evaluated the contribution of maternal IL10 rs1800896 and rs 1800872 in the susceptibility to PPROM and PTL. Based on received reliable statistical data presented above this marker can be used for prognosis PPROM in PTL, using also for example method of Multifactory Dimensionality Reduction.

Multifactory Dimensionality Reduction program helped us to create graph gene-gene interaction models with the highest cross-validation consistency and established a complex «independent» effect of polymorphic locus of genes IL4 rs2243250, IL10 rs1800896 and rs 1800872 for the appearance of PPROM and PTL in Ukrainian population. The classification ability of the cre- ated models, considering the high consistency (90\% or $100 \%$ ), confirmed the probability of a three-component model involving three abovementioned genes, which increase the risk of PPROM in PTL with an accuracy of $91.49 \%$ and specificity of $82.98 \%$ respectively.

RLN2 is produced by the corpus luteum and enters the systemic circulation in pregnancy. The action of RLN2 from the maternal decidua and fetal trophoblast is purely autocrine, it does not enter the systemic circulation. Women with spontaneous PTL have lower RLN levels in the early pregnancy but higher levels in later gestation, compared with women who deliver term. On the other hand, G. D. Bryant-Greenwood et al. analyzed that increased expression of intrauterine RLN is present in patients with PPROM without infection [9]. A recent study by I. Vogel with homogeneous Danish population improved that women who are homozygous for specific SNP in the promoter region of RLN2 have a genetic susceptibility for PTL [13].

In a study performed by Frederico G. Rocha et al. the contribution of SNP rs4742076 and rs 3758239 in the RLN2 promoter in Filipino population was shown [9]. We obtained high reliable data on SNP genes RLN2 rs4742076 and rs3758239 in Zaporizhzhia women. Therefore, multiplicative inheritance model on this sign could be used for pregnant women our Zaporizhzhia region.

Summarizing the data of repertoire of SNP genes involved in our study, we have got significant difference in all the markers, as evidenced by MDR-data, $\mathrm{x} 2$ and odds ratio. The presence of these alleles may disrupt the balance between pro- and anti-inflammatory cytokines, modify the inflammatory response, increasing the risk for PPROM and PTL.

\section{Conclusions}

1. Combination of IL4 rs2243250, IL10 rs 1800896 and rs 1800872 supports the role for functional polymorphisms in immunoregulatory genes in the development 
of PPROM and PTL.

2. Reliable clinical association between rs 4742076 and rs3758239 gene RLN2 and the PPROM in 26-34 weeks gestation in Zaporizhzhia population was established.

3. Genotyping rs 4742076 and rs 3758239 of the RLN2 gene can be used to predict PPROM in preterm pregnancies, which will facilitate the timely implementation of preventive measures and reduce the premature births rate.

Prospects for further researches. In the future, we are planning to evaluate the contribution of maternal SNPs in systemic cytokines IL1 $\beta$ (rs 1143627) and TNFa (rs1800629) and the influence in the susceptibility to PPROM and PTL in Ukrainian women. The another direction of further research will be devoted to determination the expression of innate and adaptive immunity components, specifically m-RNA quantity of TLR2, TLR4, pro-inflammatory cytokines IL-1 $\beta$ and IL-17 $\alpha$, differential regulators Th1, Th17, Treg in decidua and amniotic membranes. That will significantly enhance the understanding of PPROM and PTL leading to the formulation of preventive interventions.

Conflicts of Interest: authors have no conflict of interest to declare. Конфлікт інтересів: віАсутній.

Information about authors:

Liubomyrska K. S., MD, PhD student of the Department of Obstetrics and Gynecology, Zaporizhzhia State Medical University, Ukraine.

Kamyshnyi O. M., MD, PhD, DSc, Professor, Head of the Department of Microbiology, Virology and Immunology, Head of the Molecular-Genetic Research Division of the Medical and Laboratory Center of Zaporizhzhia State Medical University, Ukraine.

Krut Yu. Ya., MD, PhD, DSc, Professor, Head of the Department of Obstetrics and Gynecology, Zaporizhzhia State Medical University, Ukraine.

\section{Відомості про авторів:}

^юбомирська К. С., PhD аспірант каф. акушерства

та гінекології, Запорізький державний медичний університет, Україна.

Камишний О. М., А-р меА. наук, професор,

зав. каф. мікробіології, вірусології та імунології, керівник відділу молекулярно-генетичних досліджень навчального медиколабораторного центру, Запорізький державний медичний університет, Україна.

Круть Ю. Я., А-р меА. наук, професор, зав. каф. акушерства та гінекології, Запорізький Аержавний меАичний університет, Україна.

\section{Сведения об авторах:}

Аюбомирская E. C., PhD аспирант каф. акушерства и гинекологии, Запорожский государственный медицинский университет, Украина.

Камышный А. М., А-р меА. наук, профессор,

зав. каф. микробиологии, вирусологии и иммунологии, руководитель отАела молекулярно-генетических исслеАований учебного медико-лабораторного центра, Запорожский государственный медицинский университет, Украина. Круть Ю. Я., А-р меА. наук, профессор, зав. каф. акушерства и гинекологии, Запорожский государственный меАицинский университет, Украина.
Прийнято Ао Аруку / Accepted: 20.08.2018

References

[1] Stonek, F., Metzenbauer, M., Hafner, E., Phillip, K., \& Tempfer, C. (2008). Interleukin-10-1082 G/A promoter polymorphism and pregnancy complications: results of prospective cohort study in 1616 pregnant women. Acta Obstet Gynecol Scand. - Acta Obstet Gynecol Scand., 87, 430-43. doi: 10.1080/00016340801995657.

[2] Heinzmann, A., Mailaparambil, B., Mingirulli, N., \& Krueger, M. (2009). Association of Interleukin $13 / 4$ and toll-like receptor 10 with preterm births. Neonatology, 96(3), 175-81. doi: 10.1159/000210091.

[3] Ramos, B. R., Mendes, N. D., Tanikawa, A. A., Amador, M. A., dos Santos, N. P., dos Santos, S. E., et al. (2016). Ancestry informative markers and selected single nucleotide polymorphisms in immunoregulatory genes on preterm labor and preterm premature rupture of membranes: a case control study. BMC Pregnancy Childbirth, 16, 30 doi: 10.1186/s12884-016-0823-1.

[4] Zare-Bidaki, M., Sadrinia, S., Erfani, S., Afkar, E., \& Ghanbarzade, N. (2017). Antimicrobial properties of amniotic and chorionic membranes: a comparative study of two human fetal sacs. J Reprod Infertil, 18(2), 218-224

[5] Tchirikov, M., Schlabritz-Loutsevitch, N., Maher, J., Buchmann, J., Naberezhnev, Y., Winarno, A. S., \& Seliger, G. (2018). Mid-trimester preterm premature rupture of membranes (PPROM): etiology, diagnosis, classification, international recommendations of treatment options and outcome. J. Perinat. Med., 46(5), 465-488. doi: 10.1515/ jpm-2017-0027.

[6] Bukowski, R., Sadovsky, Y., Goodarzi, H., Zhang, H., Biggio, J. R., Varner, M., et al. (2017). Onset of human preterm and term birth is related to unique inflammatory transcriptome profiles at the maternal fetal interface. Peer J., 5, e3685. doi: 10.7717/peerj.3685

[7] Musilova, I., Kutová, R., Pliskova, L., Stepan, M., Menon, R., Jacobsson, B., \& Kacerovsky, M. (2015). Intraamniotic inflammation in women with preterm prelabour rupture of membranes. Plos One., 10(7), e0133929 doi: 10.1371/journal.pone.0133929.

[8] Sneikh, A. I., Ahmad, E., Jamal, M. S., Rehan, M., Assidi, M., Tayubi, I. A., et al. (2016). Spontaneous preterm birth and single nucleotide gene polymorphisms: a recent update. BMC Genomics, 17(Suppl 9), 759. doi: 10.1186/s12864-016-3089-0.

[9] Rocha, F. G., Slavin, T. P., Li, D., Tiirikainen, M. I., \& Bryant-Greenwood, G. D. (2013). Genetic associations of relaxin: preterm birth and premature rupture of fetal membranes. Am J Obstet Gynecol., 209(3), 258.e1-8. doi: 10.1016/j.ajog.2013.05.020.

[10] Salema, H., Yatchenko, E., Anosova, M., Rosenfeld, T., Altarescub, G., Grisaru-Granovsky, S., \& Birk, R. (2018). Maternal and neonatal irisin precursor gene FNDC5 polymorphism is associated with preterm birth. Gene., 649, 58-62. doi: 10.1016/j.gene.2018.01.097.

[11] National Center for Biotechnology information, dbSNP database. Retrieved from http://www.ncbi.nim.nih.gov/SNP/.

[12] Wang, Y., H. Luo, G. Che, Y. Li, J., Gao, J., Yang, Q., et al. (2018) Placental protein 14 as a potential biomarker for diagnosis of preterm premature rupture of membranes. Mol Med Rep., 18(1), 113-122. doi: $10.3892 / \mathrm{mmr} .2018 .8967$.

[13] Vogel, I., Hollegaard, M. V., Hougaard, D. M., Thorsen, P., \& Grove, J. (2009). Polymorphism in the promoter region of relaxin-2 and preterm birth: involvement of relaxin in the etiology of preterm birth. In Vivo, 23(6), 1005-9. 